Article

\title{
Sedentary Behavior and Alcohol Consumption Increase Breast Cancer Risk Regardless of Menopausal Status: A Case-Control Study
}

\author{
Jordana Carolina Marques Godinho-Mota ${ }^{1,2, *}$, Larissa Vaz Gonçalves ${ }^{1,2}$, Joao Felipe Mota ${ }^{3}$, \\ Leonardo Ribeiro Soares ${ }^{1}$, Raquel Machado Schincaglia ${ }^{2}$, Karine Anusca Martins ${ }^{2}$ (D) and \\ Ruffo Freitas-Junior ${ }^{1}(\mathbb{D})$ \\ 1 Centro Avançado de Diagnóstico da Mama, Hospital das Clínicas, Federal University of Goiás, \\ Goiania-GO 74.605-020, Brazil \\ 2 Faculty of Nutrition, Federal University of Goiás, St. 227, Block 68, Goiania-GO 74.605-080, Brazil \\ 3 Clinical and Sports Nutrition Research Laboratory (Labince), Faculty of Nutrition, Federal University of \\ Goiás, St. 227, Block 68, Goiania-GO 74.605-080, Brazil \\ * Correspondence: jordana.godinho@hotmail.com; Tel./Fax.: +55-(62)-996-001-896
}

Received: 4 July 2019; Accepted: 6 August 2019; Published: 12 August 2019

\begin{abstract}
Identification of modifiable risk factors for breast cancer is critical for primary prevention of the disease. The aim of this study was to evaluate how certain lifestyle variables modify the chances of developing breast cancer based on menopausal status. A case-control study was performed in a group of 542 women, 197 who were diagnosed with breast cancer and 344 control individuals. The groups were matched by age, body mass index, and menopausal status. Participants were evaluated for level of physical activity, alcohol consumption, smoking habit, weight, height, and waist circumference (WC). A multivariate logistic regression model was used to estimate odds ratios and $95 \%$ confidence intervals $(95 \% \mathrm{CI})$. Regular consumption of alcoholic beverages $(2.91,95 \% \mathrm{CI}$ $1.58-5.38$ and $1.86,95 \%$ CI $1.15-3.03)$ and sedentary behavior $(2.08$; $95 \%$ CI $1.12-3.85$ and $1.81 ; 95 \%$ CI 1.12-2.94) were associated with breast cancer risk in pre- and postmenopausal women, respectively. High WC (3.31, 95\% CI 1.45-7.55) was associated with an increased risk of developing breast cancer in premenopausal women. While in postmenopausal women, current smoking $(2.43,95 \%$ CI $1.01-5.83)$ or previous history of smoking $(1.90 ; 95 \%$ CI 1.14-3.14) increased the chances of developing breast cancer. Sedentary behavior and current consumption of alcoholic beverages were more likely to increase the risk of developing breast cancer regardless of menopausal status.
\end{abstract}

Keywords: breast neoplasm; risk factors; cancer prevention; lifestyle; premenopausal; postmenopausal

\section{Introduction}

Breast cancer represents a public health problem on a global scale [1]. Approximately 2 million new breast cancer cases and 626,000 deaths from the disease worldwide were estimated for the year 2018 by The International Agency for Research on Cancer (IARC) [1]. In Brazil, it is estimated that a total of 59,700 new cases will be diagnosed in 2019 , corresponding to $29.5 \%$ of cancers in women, excluding non-melanoma skin cancer [2]. Regarding mortality, in 2016 there were 16,069 deaths from breast cancer in Brazil, with higher rates in the south and southeast regions [2].

Despite the high incidence and prevalence of this cancer, the overall survival of Brazilian women is increasing. Five-year survival estimates were $76.9 \%$ and $75.2 \%$ from 2005 to 2009 and 2010 to 2014, respectively [3]. The latest multicenter study showed a five-year survival rate of $88.74 \%$ of patients with a difference in staging, molecular subtypes, and immunohistochemistry [4]. 
Identification of the etiological factors for breast cancer is important for the primary prevention of the disease [5,6]. Only $10 \%$ of breast cancer cases are thought to be hereditary [7]. There is evidence for a strong association between lifestyle variables and increased breast cancer risk related to menopausal status $[6,8,9]$. Lifestyle variables most associated with breast cancer include physical inactivity, alcohol consumption, smoking, abdominal, and total adiposity [8-16]. However, data currently available in the literature remain inconclusive and are limited by differing sample populations and methodological variations.

In this context, identification of modifiable risk factors may help to elaborate specific strategies for the control and management of breast cancer. The aim of this study was to evaluate the effects of certain lifestyle variables on the chances of developing breast cancer based on menopausal status.

\section{Materials and Methods}

\subsection{Design and Sample Size}

This case-control study was conducted from August 2014 to January 2018. In total, 542 women were enrolled in the study. There were 197 participants diagnosed with breast cancer and 344 control individuals. Participants were matched by age, body mass index, and menopausal status. A post hoc sample size analysis was performed using $G^{*}$ Power 3.1.9.2 software (Heinrich Heine Universität, Düsseldorf, Germany). An odds ratio of 1.81 for the variable postmenopausal physical activity was obtained. The proportion of the outcome for the unexposed obtained was 55.56, type I error 0.05, returning a test power $(1-\beta)$ of $99.9 \%$, and demonstrating that a suitable sample for the analysis was determined. The study was approved by the Ethics Committee of the Federal University of Goias (protocol number 751.387/2014). All study participants received oral and written information about the study and gave their written informed consent to participate in the study.

\subsection{Selection of Cases and Controls}

Women aged between 30 and 80 years with new primary breast cancer diagnoses were recruited as cases for the study. Breast cancer originating in the breast parenchyma and that had not spread beyond the breast or the lymph nodes under the arm was considered as a primary breast cancer. The participants were evaluated immediately after histological diagnoses and before systemic treatment. Women diagnosed with metastases, cutaneous neoplasms (melanoma and squamous cell carcinoma), lymphomas, ductal carcinoma in situ or with history of other cancers were not eligible for this study.

Healthy participants with similar values for body mass index (BMI), age, and menopausal stage to those in the case group were recruited as control individuals. The criteria used to determine eligibility for the control group were mammography and breasts clinical examination without pathological changes up to one year before recruitment, and absence of a personal history of breast cancer or other malignant neoplasia. The exclusion criteria for both groups were pregnancy, lactation, cognitive impairment, psychiatric illness, limb amputation or loss of mobility that would make it impossible to collect the necessary information.

\subsection{Measurements}

A personal interview was conducted by a trained researcher using a structured and standardized questionnaire. Age (full years), first-degree family history of breast cancer, marital status (with or without partner), and level of education attained (grade school, high school—complete/incomplete, and undergraduate degree) were obtained using the questionnaire.

Intensity of physical activity was measured using the short version of the International Questionnaire of Physical Activity (IPAQ) [16]. Women who reported moderate/vigorous intensity activities achieving a minimum of at least 600 MET-min/week were considered as active, and those who reported less than 600 MET-min/week) were considered as sedentary [16]. 
Smoking status was determined based on the response to the question, "Do you now or have you ever smoked cigarettes, at least one a day for one year's time?" If the answer was "yes," the participant reported the average number of cigarettes smoked per day [17]. Consumption of alcoholic drinks was calculated in grams per day according to frequency, quantity, and type of drink mentioned as habitual. Total alcohol intake was considered assuming $12.8 \mathrm{~g}$ of ethanol for $360 \mathrm{~mL}$ of regular beer, $11.3 \mathrm{~g}$ for $360 \mathrm{~mL}$ of light beer, $11.0 \mathrm{~g}$ for $120 \mathrm{~mL}$ of wine, and $14.0 \mathrm{~g}$ for $45 \mathrm{~mL}$ of liquor [18].

To ensure data reliability, measurement techniques recommended by Habicht [19] were applied in anthropometric evaluations. A stadiometer accurate to $0.1 \mathrm{~cm}$ was used to measure height. Participants were required to wear light clothing for body weight measurements. A digital scale accurate to $0.1 \mathrm{~kg}$ and with a capacity of $150 \mathrm{~kg}$ was used to evaluate body weight. BMI was calculated using the formula: Weight $(\mathrm{kg}) /$ height $(\mathrm{m})^{2}$ [20]. WC was measured on undressed participants with an inelastic tape placed at the midpoint between the anterior superior iliac crest and the last rib [21], and classified as normal $(<80 \mathrm{~cm})$ or elevated $(\geq 80 \mathrm{~cm})[22]$.

\subsection{Quality Control}

All interviewers and kinanthropometrists were previously trained and standardized in a pilot study to ensure data quality. In addition, study data were checked on three occasions; by the interviewer, by the study coordinator, and at the moment of database entry.

\subsection{Statistical Analysis}

Data were processed under the double entry method using Excel software 10.0 (version 2013, Microsoft Corporation, Redmond, WA, USA) and consistency was verified by Epi-Info ${ }^{\text {TM }} 2014$ software (version 7.1.5, Centers for Disease Control and Prevention, Atlanta, GA, USA). Statistical analysis was performed using STATA ${ }^{\circledR}$ software (version 14.0, StataCorp, College Station, TX, USA). The Shapiro-Wilk test was used to test normality and the Mann-Whitney test was used to compare groups. Data were reported as mean \pm standard deviation.

Categorical variables were expressed in absolute and relative frequencies. The Pearson's chi square test or Fisher's exact two-tailed test were used to assess the degree of homogeneity or comparability between groups. Odds ratios and 95\% confidence interval (95\% CI) for developing breast cancer based on menopausal status were calculated. Binary logistic regression and multiple logistic regression calculations were performed using the backward method $(p<0.20)$ and adjusted by BMI according to the automatic selection of the statistical program. The data were expressed in the form of a Forest Plot. The level of significance used for all tests was $5 \%$.

\section{Results}

Demographic characteristics are shown in Table 1. In postmenopausal women, the control group had a higher percentage of women with a completed undergraduate degree than the case group. No differences were observed based on age and marital status between both groups. Family history of breast cancer did not differ in pre- (cases: $10.0 \%$ vs. controls: $12.8 \% ; p=0.541$ ) and postmenopausal stages (cases: $10.3 \%$ vs. controls: $10.4 \% ; p=0.930$ ). 
Table 1. Demographic and economic characteristics among participants according to menopausal status.

\begin{tabular}{ccccccc}
\hline & \multicolumn{3}{c}{ Premenopausal 213 (39.37) } & \multicolumn{2}{c}{ Postmenopausal 328 (60.63) } \\
\cline { 2 - 7 } & Cases & Controls & $p$-Value & Cases & Controls & $p$-Value \\
\hline & $80(37.56)$ & $133(62.44)$ & & $117(35.67)$ & $211(64.33)$ & \\
\hline Age (years) & $41.84 \pm 6.62$ & $41.41 \pm 7.01$ & 0.488 & $59.21 \pm 8.78$ & $58.77 \pm 8.22$ & 0.722 \\
Marital status & & & 0.594 & & & 0.184 \\
With partner & $54(67.50)$ & $85(63.91)$ & & $61(52.14)$ & $126(59.72)$ & \\
Without partner & $26(32.50)$ & $48(36.09)$ & $0.328^{*}$ & $56(47.86)$ & $85(40.28)$ & \\
$\quad$ Schooling & $5(6.33)$ & $3(2.34)$ & & $14(12.73)$ & $10(5.03)$ & \\
$\quad \begin{array}{c}\text { Grade school } \\
\text { Incomplete high school }\end{array}$ & $9(11.39)$ & $13(10.16)$ & & $44(40.00)$ & $49(24.62)$ & \\
High school and & $65(82.28)$ & $112(87.50)$ & & $52(47.27)$ & $140(70.35)$ & \\
undergrad course & & & & &
\end{tabular}

Values presented in absolute $(n)$ and relative (\%) frequencies or mean \pm standard deviation. $p$-value-Pearson's Chi-square test ( ${ }^{*}$ Fisher's exact two-tailed test or Mann-Whitney test). Significance level of $5 \%$.

Considering the variables associated with lifestyle, women in the case group were mostly sedentary and reported higher consumption of cigarettes and alcoholic beverages, regardless of menopausal status (Table 2). In premenopausal status, the control group had an average higher body weight compared to case group ( $p=0.03$, Table 3$)$.

Table 2. Lifestyle characteristics among participants according to menopausal status.

\begin{tabular}{|c|c|c|c|c|c|c|}
\hline & \multicolumn{3}{|c|}{ Premenopausal 213 (39.37) } & \multicolumn{3}{|c|}{ Postmenopausal 328 (60.63) } \\
\hline & Cases & Controls & $p$-Value & Cases & Controls & $p$-Value \\
\hline & $80(37.56)$ & $133(62.44)$ & & $117(35.67)$ & $211(64.33)$ & \\
\hline Physical activity level * & & & 0.011 & & & 0.021 \\
\hline Active & $29(36.25)$ & $73(54.89)$ & & $52(44.44)$ & $123(58.29)$ & \\
\hline Sedentary & $51(63.75)$ & $60(45.11)$ & & $65(55.56)$ & $88(41.71)$ & \\
\hline $\begin{array}{l}\text { Cigarette consumption } \\
\text { (units/day) }\end{array}$ & $16.18 \pm 9.99$ & $8.72 \pm 4.90$ & $<0.005$ & $17.59 \pm 12.48$ & $9.22 \pm 6.31$ & $<0.001$ \\
\hline Smoking habit * & & & 0.271 & & & 0.005 \\
\hline Never smoker & $58(72.50)$ & $108(81.20)$ & & $57(48.72)$ & $141(66.82)$ & \\
\hline Smoker & $6(7.50)$ & $5(3.76)$ & & $12(10.26)$ & $12(5.69)$ & \\
\hline Ex-smoker & $16(20.00)$ & $20(15.04)$ & & 48 (41.03) & $58(27.49)$ & \\
\hline $\begin{array}{l}\text { Ethanol consumption } \\
\text { (g/day) }\end{array}$ & $1.59 \pm 1.04$ & $0.82 \pm 0.35$ & $<0.001$ & $1.44 \pm 0.76$ & $0.90 \pm 0.39$ & $<0.001$ \\
\hline Alcoholic habit * & & & 0.001 & & & 0.016 \\
\hline Not & $33(41.25)$ & $86(64.66)$ & & $65(55.56)$ & $146(69.19)$ & \\
\hline Yes & $47(58.75)$ & $47(35.34)$ & & $52(44.44)$ & $65(30.81)$ & \\
\hline
\end{tabular}

Values presented in absolute $(n)$ and relative (\%) or mean \pm standard deviation frequencies. $p$-value-Pearson's chi-square test ( ${ }^{*}$ Fisher's exact two-tailed test or Mann-Whitney test). Significance level of $5 \%$.

Table 3. Anthropometric characteristics among participants according to menopausal status.

\begin{tabular}{ccccccc}
\hline & \multicolumn{2}{c}{ Premenopausal 213 (39.37) } & \multicolumn{2}{c}{ Postmenopausal 328 (60.63) } \\
\cline { 2 - 7 } & Cases & Controls & $p$-Value & Cases & Controls & $p$-Value \\
\hline & $80(37.56)$ & $133(62.44)$ & & $117(35.67)$ & $211(64.33)$ \\
\hline Height (meters) & $1.58 \pm 0.06$ & $1.60 \pm 0.06$ & 0.19 & $1.55 \pm 0.06$ & $1.57 \pm 0.06$ & 0.07 \\
Body weight $(\mathrm{kg})$ & $66.01 \pm 12.85$ & $69.66 \pm 13.84$ & 0.04 & $68.37 \pm 13.61$ & $68.51 \pm 13.14$ & 0.78 \\
BMI & $26.26 \pm 4.73$ & $27.21 \pm 5.34$ & 0.19 & $28.28 \pm 5.62$ & $28.02 \pm 5.09$ & 0.96 \\
Normal weight * & 0 & $1(0.75)$ & 0.06 & $2(1.71)$ & $3(1.42)$ & 0.74 \\
Overweight & $40(50.00)$ & $85(63.91)$ & & $79(67.52)$ & $151(71.56)$ & \\
Obesity & $40(50.00)$ & $47(35.34)$ & & $36(30.77)$ & $57(27.01)$ & 0.39 \\
Waist circumference & $87.61 \pm 11.79$ & $87.75 \pm 12.79$ & 0.97 & $93.33 \pm 12.08$ & $91.73 \pm 12.66$ & 0.31 \\
Low risk $(<80 \mathrm{~cm})^{*}$ & $16(20.78)$ & $41(32.54)$ & 0.07 & $12(10.91)$ & $31(15.05)$ & \\
Increased risk $(\geq 80 \mathrm{~cm})$ & $61(79.22)$ & $85(67.46)$ & & $98(89.09)$ & $175(84.95)$ & \\
\hline
\end{tabular}

Values presented in absolute $(n)$ and relative (\%) or mean \pm standard deviation frequencies. $p$-value- $\left({ }^{*}\right.$ Fisher's exact two-tailed test; or Mann-Whitney test). Significance level of $5 \%$.

After multiple logical regression analyses, sedentary behavior and regular consumption of alcoholic beverages were found to be risk factors for breast cancer regardless of menopausal status (Figures 1 and 2). In addition, elevated WC increased the risk of breast cancer in premenopausal women (3.31; CI 1.45-7.55, $p=0.005$; Figure 1). On the other hand, current smoking (2.43, CI 1.01-5.83, 
$p=0.03)$ or a previous history of smoking $(1.90$, CI 1.14-3.14, $p=0.006)$ increased the risk of breast cancer in postmenopausal women (Figure 2).

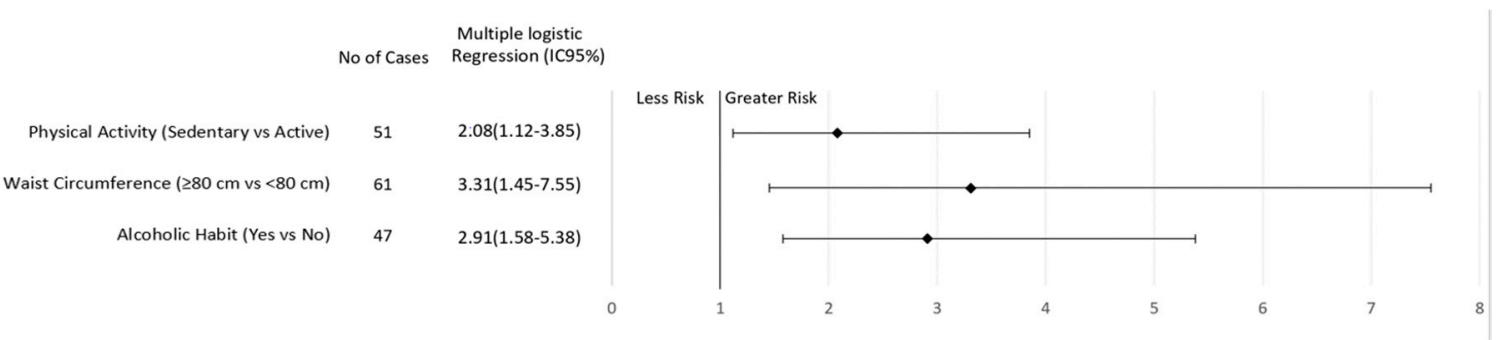

Figure 1. Association of lifestyle behavior and breast cancer risk in women according to premenopausal status.

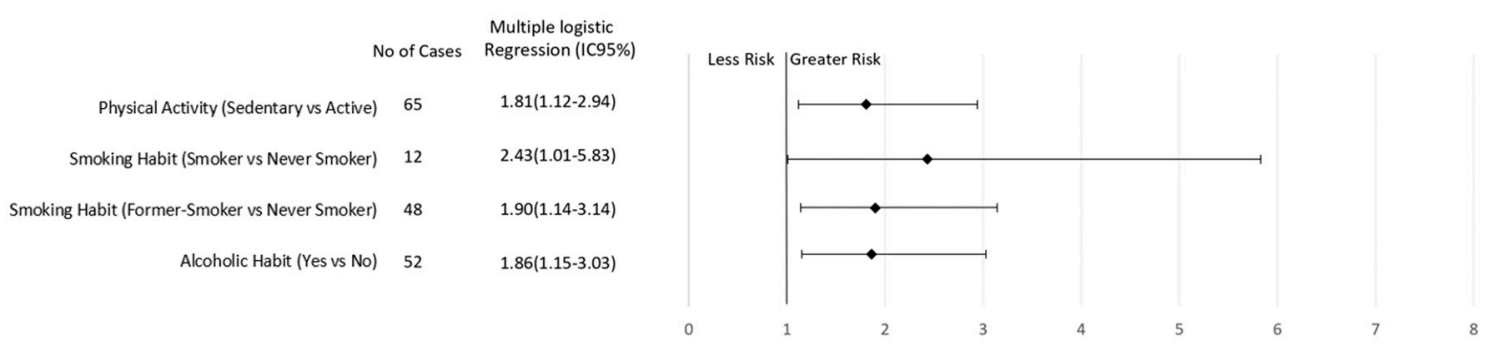

Figure 2. Association of lifestyle behavior and breast cancer risk in women according to postmenopausal status.

\section{Discussion}

Our results provide a more comprehensive view of the relationship between lifestyle variables and breast cancer when menopausal status is considered. A sedentary lifestyle and regular consumption of alcoholic beverages both increased the risk of developing breast cancer, regardless of menopausal status. In addition, abdominal adiposity was associated with a 3.3-fold increase in the risk of developing breast cancer in premenopausal women. For postmenopausal women, a current or past history of smoking increased the risk of developing breast cancer.

Epidemiological studies have reported a consistent association between the regular consumption of alcoholic beverages and the development of breast cancer [23,24]. Following the re-analysis of individual data from 53 epidemiological studies which associated breast neoplasia with daily consumption of $10 \mathrm{~g}$ of ethanol [25], a meta-analysis found sufficient evidence that even light alcohol consumption can significantly increase disease risk [26]. Possible mechanisms for this link include high concentrations of bioactive free estrogen and androgens, a pro-inflammatory environment, and presence of plasma insulin-like growth factors which promote tumor progression $[6,26]$.

Our study reinforces that lifestyle variables have different associations with breast cancer risk based on menopausal status $[6,8,11,13,15,27,28]$. To our knowledge, this is the first study to carry out an investigation into the effects of lifestyle variables on breast cancer risk based on the menopausal status in Brazilian women. This will allow for greater nationwide awareness about effects of these relationships on the health status of women. Prospective and population-based studies have demonstrated a direct relationship between a sedentary lifestyle and the risk of developing breast cancer $[23,27,29,30]$. However, this correlation may vary with age, menopausal status, and tumor biology [23,27-35]. In this study, the association was strongly inversed for both menopausal status and age.

The biological mechanisms by which physical activity may reduce the risk of breast cancer development remain uncertain $[23,27,29,30]$. However, these mechanisms are probably associated with maintenance or reduction of body weight, abdominal adiposity, serum estrogen levels, and insulin resistance [23,32-34]. In addition, sedentary behavior combined with other unhealthy habits such 
as smoking, high consumption of alcohol and saturated fatty acids may increase the risk for breast neoplasia $[10,23,36]$.

In this study, WC was observed as a predictor for developing breast cancer in premenopausal women, regardless of BMI. Our findings confirm that the relationship between obesity and breast cancer is complex and shows divergence between ethnic groups [37]. After adjusting for BMI, WC became the most important adiposity marker in premenopausal women with breast cancer [38-40]. This may be explained by the relationship between central adiposity and high concentrations of cytokines, insulin, insulin-like growth factor 1 (IGF-1) [37], estradiol, and sex hormone binding globulin in premenopausal women [41].

Although smoking is considered an important risk factor for various types of cancer according to the International Agency for Research, its effects on breast cancer risk remain inconclusive [42]. However, recent studies found a positive association between smoking habits and breast cancer risk, which is consistent with our study $[43,44]$. Tobacco contains different chemical compounds which may contribute to carcinogenesis through various pathways, including induction of mutations, increased inflammation and oxidative stress, and epigenetic mechanisms [45]. It is suggested that over time these pro-inflammatory effects supersede those of anti-estrogens that mitigate breast cancer risk [46].

In a study conducted on a cohort of women from 17 countries in North and Latin America, Europe, and Asia, authors observed a 1.33-fold increase in the risk of developing breast cancer in smokers compared to non-smokers, without accounting for differences in the type of tumor and age of diagnosis [47]. Recent findings also indicate that the positive correlation increases with a greater number of cigarettes consumed per day and higher exposure time [47,48]. We found that smoking was associated with breast cancer only in the postmenopausal period, which may be explained by longer duration of exposure.

Some potential limitations of our study were the case-control study design, the assessment of physical activity level using a questionnaire, and the absence of food consumption analysis. In addition, Jewish ancestry, breast density, and radiation exposure from computed tomography were not evaluated, which could influence the results. Several studies have reported higher rates of breast cancer 1 and 2 (BRCA1 and 2) gene mutations in Ashkenazi Jewish women [49,50]. However, Ashkenazi women living in Brazilian cities showed a relatively lower than expected breast cancer mortality pattern [51]. The authors raised the hypothesis that germ mutations may be modulated by some environmental factors that perhaps could act as protective factors, delaying the mutation expression [51]. On the other hand, high breast density is considered a risk factor for breast cancer and have a synergistic interaction with overweight [52].

Our study concluded that a sedentary lifestyle and regular consumption of alcoholic beverages were considered risk factors for breast cancer in women, regardless of menopausal status. In addition, increased abdominal adiposity and smoking posed a risk for premenopausal and premenopausal breast cancer, respectively.

Author Contributions: Conceptualization, J.C.M.G.-M. and R.F.-J.; methodology, J.C.M.G.-M., L.V.G., K.A.M., J.F.M., R.M.S., R.F.-J. and L.R.S.; formal analysis, J.C.M.G.-M., L.R.S. and R.M.S.; investigation, J.C.M.G.-M., L.V.G. and L.R.S.; data curation, J.C.M.G.-M., L.V.G., L.R.S. and R.M.S.; writing-original draft preparation, J.C.M.G.-M., L.V.G. and R.M.S.; writing-review and editing, J.C.M.G.-M., L.V.G., K.A.M., J.F.M., R.M.S., R.F.-J. and L.R.S. All authors approved the final version.

Acknowledgments: We thank all of the research group on Nutrition and Breast Cancer of the Faculty of Nutrition of the Federal University of Goiás, especially the students who assisted in all stages of the study. In addition, we emphasize the importance of care with patients, by the CORA team. All those who directly or indirectly strengthen actions for the health of Brazilian women.

Conflicts of Interest: The authors declare no conflict of interest. 


\section{References}

1. Bray, F.; Ferlay, J.; Soerjomataram, I.; Siegel, R.L.; Torre, L.A.; Jemal, A. Global cancer statistics 2018: GLOBOCAN estimates of incidence and mortality worldwide for 36 cancers in 185 countries. CA Cancer J. Clin. 2018, 68, 394-424. [CrossRef] [PubMed]

2. Instituto Nacional de Cancer José Alencar Gomes da Silva (INCA). Estimate 2018: Cancer Incidence in Brazil; INCA: Rio de Janeiro (RJ), Brazil, 2017.

3. Allemani, C.; Matsuda, T.; Di Carlo, V.; Harewood, R.; Matz, M.; Nikšić, M.; Bonaventure, A.; Valkov, M.; Johnson, C.J.; Estève, J.; et al. CONCORD Working Group. Global surveillance of trends in cancer survival 2000-14 (CONCORD-3): Analysis of individual records for 37513025 patients diagnosed with one of 18 cancers from 322 population-based registries in 71 countries. Lancet 2018, 391, 1023-1075. [CrossRef]

4. Simon, S.D.; Bines, J.; Werutsky, G.; Nunes, J.S.; Pacheco, F.C.; Segalla, J.G.; Gomes, A.J.S.; Adam, V.E.B.; Gimenes, D.L.; Crocamo, S.; et al. Characteristics and prognosis of stage I-III breast cancer subtypes in Brazil: The AMAZONA retrospective cohort study. Breast 2019, 44, 113-119. [CrossRef] [PubMed]

5. Kolak, A.; Kamińska, M.; Sygit, K.; Budny, A.; Surdyka, D.; Kukiełka-Budny, B.; Burdan, F. Primary and secondary prevention of breast cancer. Ann. Agric. Environ. Med. 2017, 24, 549-553. [CrossRef] [PubMed]

6. McKenzie, F.; Ferrari, P.; Freisling, H.; Chajès, V.; Rinaldi, S.; de Batlle, J.; Dahm, C.C.; Overvad, K.; Baglietto, L.; Dartois, L.; et al. Healthy lifestyle and risk of breast cancer among postmenopausal women in the European Prospective Investigation into Cancer and Nutrition cohort study. Int. J. Cancer 2015, 136, 2640-2648. [CrossRef] [PubMed]

7. Couch, F.J.; Shimelis, H.; Hu, C.; Hart, S.N.; Polley, E.C.; Na, J.; Hallberg, E.; Moore, R.; Thomas, A.; Lilyquist, J.; et al. Associations Between Cancer Predisposition Testing Panel Genes and Breast Cancer. JAMA Oncol. 2017, 3, 1190-1196. [CrossRef] [PubMed]

8. Tamimi, R.M.; Spiegelman, D.; Smith-Warner, S.A.; Wang, M.; Pazaris, M.; Willett, W.C.; Eliassen, A.H.; Hunter, D.J. Population Attributable Risk of Modifiable and Nonmodifiable Breast Cancer Risk Factors in Postmenopausal Breast Cancer. Am. J. Epidemiol. 2016, 184, 884-893. [CrossRef] [PubMed]

9. Godinho-Mota, J.C.M.; Martins, K.A.; Vaz-Gonçalves, L.; Mota, J.F.; Soares, L.R.; Freitas-Junior, R. Visceral adiposity increases the risk of breast cancer: A case-control study. Nutr. Hosp. 2018, 35, 576-581. [PubMed]

10. Arthur, R.; Wassertheil-Smoller, S.; Manson, J.E.; Luo, J.; Snetselaar, L.; Hastert, T.; Caan, B.; Qi, L.; Rohan, T. The Combined Association of Modifiable Risk Factors with Breast Cancer Risk in the Women's Health Initiative. Cancer Prev. Res. (Phila) 2018, 11, 317-326. [CrossRef]

11. Godinho-Mota, J.C.M.; Gonçalves, L.V.; Soares, L.R.; Mota, J.F.; Martins, K.A.; Freitas-Junior, I.; Freitas-Junior, R. Abdominal Adiposity and Physical Inactivity Are Positively Associated with Breast Cancer: A Case-Control Study. BioMed Res. Int. 2018, 2018, 4783710. [CrossRef]

12. Picon-Ruiz, M.; Morata-Tarifa, C.; Valle-Goffin, J.J.; Friedman, E.R.; Slingerland, J.M. Obesity and adverse breast cancer risk and outcome: Mechanistic insights and strategies for intervention. CA Cancer J. Clin. 2017, 67, 378-397. [CrossRef] [PubMed]

13. Inumaru, L.E.; Irineu Gomes Duarte Quintanilha, M.; Aparecida da Silveira, É.; Veloso Naves, M.M. Risk and protective factors for breast cancer in Midwest of Brazil. J. Environ. Public Health 2012, 2012, 356851. [CrossRef] [PubMed]

14. Winters, S.; Martin, C.; Murphy, D.; Shokar, N.K. Breast Cancer Epidemiology, Prevention, and Screening. Prog. Mol. Biol. Transl. Sci. 2017, 151, 1-32. [PubMed]

15. Morales, L.; Alvarez-Garriga, C.; Matta, J.; Ortiz, C.; Vergne, Y.; Vargas, W.; Acosta, H.; Ramírez, J.; Perez-Mayoral, J.; Bayona, M. Factors associated with breast cancer in Puerto Rican women. J. Epidemiol. Glob. Health 2013, 3, 205-215. [CrossRef] [PubMed]

16. Craig, C.L.; Marshall, A.L.; Sjöström, M.; Bauman, A.E.; Booth, M.L.; Ainsworth, B.E.; Pratt, M.; Ekelund, U.; Yngve, A.; Sallis, J.F.; et al. International physical activity questionnaire: 12-country reliability and validity. Med. Sci. Sports Exerc. 2003, 35, 1381-1395. [CrossRef] [PubMed]

17. Gaudet, M.M.; Gapstur, S.M.; Sun, J.; Diver, W.R.; Hannan, L.M.; Thun, M.J. Active smoking and breast cancer risk: Original cohort data and meta-analysis. J. Natl. Cancer Inst. 2013, 105, 515-525. [CrossRef] [PubMed] 
18. Wang, J.; Heng, Y.J.; Eliassen, A.H.; Tamimi, R.M.; Hazra, A.; Carey, V.J.; Ambrosone, C.B.; de Andrade, V.P.; Brufsky, A.; Couch, F.J.; et al. Alcohol consumption and breast tumor gene expression. Breast Cancer Res. 2017, 19, 108. [CrossRef]

19. Habicht, J. Estandarización de Métodos Epidemiológicos Cuantitativos Sobre el Terreno. Bol. Oficina Sanit. Panam. 1974, 76, 375-384.

20. Organization, W.H. Obesity: Preventing and Managing the Global Epidemic; World Health Organization: Geneva, Switzerland, 2000.

21. Lohman, T.G.; Roche, A.F.; Martorell, R. Anthropometric Standardization Reference Manual; Human Kinetics Books: Champaign, IL, USA, 1988; 177p.

22. Lean, M.E.; Han, T.S.; Morrison, C.E. Waist circumference as a measure for indicating need for weight management. BMJ 1995, 311, 158-161. [CrossRef]

23. Kerr, J.; Anderson, C.; Lippman, S.M. Physical activity, sedentary behaviour, diet, and cancer: An update and emerging new evidence. Lancet Oncol. 2017, 18, e457-e471. [CrossRef]

24. Liu, Y.; Colditz, G.A.; Rosner, B.; Berkey, C.S.; Collins, L.C.; Schnitt, S.J.; Connolly, J.L.; Chen, W.Y.; Willett, W.C.; Tamimi, R.M. Alcohol intake between menarche and first pregnancy: A prospective study of breast cancer risk. J. Natl. Cancer Inst. 2013, 105, 1571-1578. [CrossRef] [PubMed]

25. Hamajima, N.; Hirose, K.; Tajima, K.; Rohan, T.; Calle, E.E.; Heath, C.W.; Coates, R.J.; Liff, J.M.; Talamini, R.; Chantarakul, N.; et al. Alcohol, tobacco and breast cancer-collaborative reanalysis of individual data from 53 epidemiological studies, including 58,515 women with breast cancer and 95,067 women without the disease. Br. J. Cancer 2002, 87, 1234-1245. [PubMed]

26. Bagnardi, V.; Rota, M.; Botteri, E.; Tramacere, I.; Islami, F.; Fedirko, V.; Scotti, L.; Jenab, M.; Turati, F.; Pasquali, E.; et al. Light alcohol drinking and cancer: A meta-analysis. Ann Oncol. 2013, 24, 301-308. [CrossRef] [PubMed]

27. Eliassen, A.H.; Hankinson, S.E.; Rosner, B.; Holmes, M.D.; Willett, W.C. Physical activity and risk of breast cancer among postmenopausal women. Arch. Intern. Med. 2010, 170, 1758-1764. [CrossRef] [PubMed]

28. Kawai, M.; Kakugawa, Y.; Nishino, Y.; Hamanaka, Y.; Ohuchi, N.; Minami, Y. Anthropometric factors, physical activity, and breast cancer risk in relation to hormone receptor and menopausal status in Japanese women: A case-control study. Cancer Causes Control 2013, 24, 1033-1044. [CrossRef] [PubMed]

29. Moore, S.C.; Lee, I.M.; Weiderpass, E.; Campbell, P.T.; Sampson, J.N.; Kitahara, C.M.; Keadle, S.K.; Arem, H.; Berrington de Gonzalez, A.; Hartge, P.; et al. Association of Leisure-Time Physical Activity with Risk of 26 Types of Cancer in 1.44 Million Adults. JAMA Intern. Med. 2016, 176, 816-825. [CrossRef] [PubMed]

30. Ma, H.; Xu, X.; Clague, J.; Lu, Y.; Togawa, K.; Wang, S.S.; Clarke, C.A.; Lee, E.; Park, H.L.; Sullivan-Halley, J.; et al. Recreational physical activity and risk of triple negative breast cancer in the California Teachers Study. Breast Cancer Res. 2016, 18, 62. [CrossRef]

31. Lope, V.; Martín, M.; Castelló, A.; Casla, S.; Ruiz, A.; Baena-Cañada, J.M.; Casas, A.M.; Calvo, L.; Bermejo, B.; Muñoz, M.; et al. Physical activity and breast cancer risk by pathological subtype. Gynecol. Oncol. 2017, 144, 577-585. [CrossRef]

32. Ballard-Barbash, R.; Friedenreich, C.M.; Courneya, K.S.; Siddiqi, S.M.; McTiernan, A.; Alfano, C.M. Physical activity, biomarkers, and disease outcomes in cancer survivors: A systematic review. J. Natl. Cancer Inst. 2012, 104, 815-840. [CrossRef]

33. De Boer, M.C.; Wörner, E.A.; Verlaan, D.; van Leeuwen, P.A.M. The Mechanisms and Effects of Physical Activity on Breast Cancer. Clin. Breast Cancer 2017, 17, 272-278. [CrossRef]

34. Hibler, E. Epigenetics and Colorectal Neoplasia: The Evidence for Physical Activity and Sedentary Behavior. Curr. Colorectal. Cancer Rep. 2015, 11, 388-396. [CrossRef]

35. Hardefeldt, P.J.; Penninkilampi, R.; Edirimanne, S.; Eslick, G.D. Physical Activity and Weight Loss Reduce the Risk of Breast Cancer: A Meta-analysis of 139 Prospective and Retrospective Studies. Clin. Breast Cancer 2018, 18, e601-e612. [CrossRef] [PubMed]

36. Paxton, R.J.; Garner, W.; Dean, L.T.; Logan, G.; Allen-Watts, K. Health Behaviors and Lifestyle Interventions in African American Breast Cancer Survivors: A Review. Front. Oncol. 2019, 9, 3. [CrossRef] [PubMed]

37. Amadou, A.; Ferrari, P.; Muwonge, R.; Moskal, A.; Biessy, C.; Romieu, I.; Hainaut, P. Overweight, obesity and risk of premenopausal breast cancer according to ethnicity: A systematic review and dose-response meta-analysis. Obes. Rev. 2013, 14, 665-678. [CrossRef] [PubMed] 
38. Nagrani, R.; Mhatre, S.; Rajaraman, P.; Soerjomataram, I.; Boffetta, P.; Gupta, S.; Parmar, V.; Badwe, R.; Dikshit, R. Central obesity increases risk of breast cancer irrespective of menopausal and hormonal receptor status in women of South Asian Ethnicity. Eur. J. Cancer 2016, 66, 153-161. [CrossRef] [PubMed]

39. White, A.J.; Nichols, H.B.; Bradshaw, P.T.; Sandler, D.P. Overall and central adiposity and breast cancer risk in the Sister Study. Cancer 2015, 121, 3700-3708. [CrossRef] [PubMed]

40. Lee, K.R.; Hwang, I.C.; Han, K.D.; Jung, J.; Seo, M.H. Waist circumference and risk of breast cancer in Korean women: A nationwide cohort study. Int. J. Cancer 2018, 142, 1554-1559. [CrossRef]

41. Paxton, R.J.; King, D.W.; Garcia-Prieto, C.; Connors, S.K.; Hernandez, M.; Gor, B.J.; Jones, L.A. Associations between body size and serum estradiol and sex hormone-binding globulin levels in premenopausal African American women. J. Clin. Endocrinol. Metab. 2013, 98, E485-E490. [CrossRef] [PubMed]

42. International Agency for Research on Cancer. IARC monographs on the evaluation of carcinogenic risks to humans, volume 100 (E). A review of human carcinogens: Personal habits and indoor combustions. Lyon Fr. IARC 2012, 100, 43-213.

43. Macacu, A.; Autier, P.; Boniol, M.; Boyle, P. Active and passive smoking and risk of breast cancer: A meta-analysis. Breast Cancer Res. Treat. 2015, 154, 213-224. [CrossRef]

44. Gram, I.T.; Park, S.-Y.; Kolonel, L.N.; Maskarinec, G.; Wilkens, L.R.; Henderson, B.E.; Le Marchand, L. Smoking and risk of breast cancer in a racially/ethnically diverse population of mainly women who do not drink alcohol: The MEC Study. Am. J. Epidemiol. 2015, 182, 917-925. [CrossRef]

45. World Health Organization (WHO). International Agency for Research on Cancer (IARC) Monographs on the Evaluation of Carcinogenic Risks to Humans. Tobacco Smoke and Involuntary Smoking. Available online: https://publications.iarc.fr/101 (accessed on 4 February 2019).

46. Perera, F.P.; Estabrook, A.; Hewer, A.; Channing, K.; Rundle, A.; Mooney, L.A.; Whyatt, R.; Phillips, D.H. Carcinogen-DNA adducts in human breast tissue. Cancer Epidemiol. Biomark. Prev. 1995, 4, 233-238.

47. Ko, K.P.; Kim, S.J.; Huzarski, T.; Gronwald, J.; Lubinski, J.; Lynch, H.T.; Armel, S.; Park, S.K.; Karlan, B.; Singer, C.F.; et al. The association between smoking and cancer incidence in BRCA1 and BRCA2 mutation carriers. Int. J. Cancer 2018, 142, 2263-2272. [CrossRef]

48. Gao, C.M.; Ding, J.H.; Li, S.P.; Liu, Y.T.; Qian, Y.; Chang, J.; Tang, J.H.; Tajima, K. Active and passive smoking, and alcohol drinking and breast cancer risk in chinese women. Asian Pac. J. Cancer Prev. 2013, 14, 993-996. [CrossRef]

49. Rosenthal, E.; Moyes, K.; Arnell, C.; Evans, B.; Wenstrup, R.J. Incidence of BRCA1 and BRCA2 non-founder mutations in patients of Ashkenazi Jewish ancestry. Breast Cancer Res. Treat. 2015, 149, 223-227. [CrossRef]

50. Walsh, T.; Mandell, J.B.; Norquist, B.M.; Casadei, S.; Gulsuner, S.; Lee, M.K.; King, M.C. Genetic Predisposition to Breast Cancer Due to Mutations Other Than BRCA1 and BRCA2 Founder Alleles Among Ashkenazi Jewish Women. JAMA Oncol. 2017, 3, 1647-1653. [CrossRef]

51. Koifman, S.; Koifman, R.J. Breast cancer mortality among Ashkenazi Jewish women in São Paulo and Porto Alegre, Brazil. Breast Cancer Res. 2001, 3, 270-275. [CrossRef]

52. Shieh, Y.; Scott, C.G.; Jensen, M.R.; Norman, A.D.; Bertrand, K.A.; Pankratz, V.S.; Brandt, K.R.; Visscher, D.W.; Shepherd, J.A.; Tamimi, R.M.; et al. Body mass index, mammographic density, and breast cancer risk by estrogen receptor subtype. Breast Cancer Res. 2019, 21, 48. [CrossRef]

(C) 2019 by the authors. Licensee MDPI, Basel, Switzerland. This article is an open access article distributed under the terms and conditions of the Creative Commons Attribution (CC BY) license (http://creativecommons.org/licenses/by/4.0/). 